Research Article

\title{
Effect of Environmental Stressors on the Distribution and Abundance of Macroinvertebrates in Upper Awash River at Chilimo Forest, West Shewa, Ethiopia
}

\author{
Misgana Dabessa, ${ }^{1}$ Aschalew Lakew, ${ }^{2}$ Prabha Devi, ${ }^{3}$ and Hirpasa Teressa ${ }^{4}{ }^{4}$ \\ ${ }^{1}$ Chemical and Construction Inputs Industry Development Institute, Addis Ababa, Ethiopia \\ ${ }^{2}$ Ethiopian Institute of Agricultural Research, National Fishery and Aquatic Life Research Centre, Sebeta, Ethiopia \\ ${ }^{3}$ Ambo University, Department of Biology, Ambo, Ethiopia \\ ${ }^{4}$ Wolkite University, Department of Biology, Wolkite, Ethiopia
}

Correspondence should be addressed to Hirpasa Teressa; hirpaifet100@gmail.com

Received 28 November 2020; Revised 1 September 2021; Accepted 23 November 2021; Published 2 December 2021

Academic Editor: Marco Cucco

Copyright (c) 2021 Misgana Dabessa et al. This is an open access article distributed under the Creative Commons Attribution License, which permits unrestricted use, distribution, and reproduction in any medium, provided the original work is properly cited.

\begin{abstract}
Ethiopia is experiencing deterioration in river quality resulting in adverse effects on human health and hydrobionts. This study aimed to analyse the effects of specific environmental stressors on the distribution and abundance of macroinvertebrates in the Upper Awash River. The study was conducted from January 2018 to March 2018. Macroinvertebrates were collected from five sites using standard handheld nets. Physicochemical parameters including electrical conductivity, dissolved oxygen, total phosphorous, nitrate-nitrogen, $\mathrm{pH}$, dissolved oxygen and water temperature that can affect the distribution and abundance of macroinvertebrates were assessed. A total of 14,465 individuals belonging to 33 families of insects and 5 families of the noninsect group were identified. Among all recorded taxa, Diptera was the most abundant and diversified order. Macroinvertebrates among the five sites showed variation in species evenness, richness, and Shannon Diversity Index. Values obtained from biotic indices and environmental parameters indicated the presence of organic pollution at different levels. The impacted downstream site paper mill waste (Walgata) had the relatively highest H-FBI index followed by Osole (more agricultural activities) indicating that Walgata and Osole were poorer in benthic faunal diversity than other sites. In addition, as habitat and water quality degradation increased, the number and percentage of Plecoptera, Ephemeroptera, and Trichoptera (EPT) decreased. The selected metrics will be also useful for the monitoring and assessment of the riverine systems and to access the impact of different stressors. As perturbation increased, species diversity, ETHbios index, Average Score Per Taxon, and family richness decreased, while the percentage of Chironomidae, Diptera, Dominant Taxa, and Hilsenhoff Family-Level Biotic Index increased indicating that tolerant species become abundant in degraded river bodies. Environmental protection agencies of governmental and nongovernmental organizations should make awareness for the local people so that they reduce activities that affect the river. Paper factory should also monitor its effluent from directly discharging into the Upper Awash River.
\end{abstract}

\section{Introduction}

Water is a vital resource that provides many provisioning, regulatory, and cultural ecosystem services [1]. Ethiopia, like other developing countries, is experiencing deterioration in river quality resulting in adverse effects on human health, increased water treatment costs, and reduction in fisheries yields [2-4]. Anthropogenic changes in the physical and chemical habitat of freshwaters (e.g., temperature, $\mathrm{pH}$, dissolved oxygen, conductivity, total phosphorous, and nitrate) bring diverse biological effects, both subtle and severe [5]. Such changes indicate that the ecosystem and organisms therein are under stress. These changes in the aquatic environment can be used to indicate the pollution level of the water body and possible risks to human health [6]. Each aquatic organism has particular requirements with respect to 
the biological, chemical, and physical conditions of its habitat. Therefore, perturbations in these conditions result in the reduction in species numbers, a change in species dominance, or total loss of sensitive species [7].

Conventional physicochemical methods (water quality parameters such as temperature, $\mathrm{pH}$, dissolved oxygen, conductivity, total phosphorous, and nitrate) are used in some rivers of Ethiopia for monitoring river water quality. However, the effects of a variety of stressors cannot be detected through these methods, and water management decisions may suffer from deficient knowledge of environmental consequences with this method. Monitoring water quality is essential to determine the water quality status and to improve the environmental conditions and the related public health concerns [8]. Macroinvertebrates are known to be useful bioindicators to determine the integrity status of freshwater ecosystems, as their community consists of a broad range of species with different tolerances to water pollution [3]. In addition, macroinvertebrates (i) are ubiquitous, abundant, and easy to collect, (ii) respond very rapidly to pollution, (iii) have long life spans, which provide an integrated temporal record of water quality, and (iv) are representative of the local conditions due to their relative sedentary behaviour [9]. As a result, benthic macroinvertebrates are often the taxa of choice for biomonitoring in streams and rivers $[10,11]$ as they are good indicators of several anthropogenic pressures such as water pollution [12] and geomorphological alterations [13].

Recently, biological indicators including macroinvertebrates and diatoms get more acceptance as routine monitoring tools especially in developed countries [5]. In the last decade, many studies have been conducted in Ethiopia using macroinvertebrates as bioindicators [14-19]. However, there is no study conducted on macroinvertebrate indicators to evaluate the specific effect of water pollution on macroinvertebrates. In addition, the Chilimo Forest has steep slopes that are susceptible to soil erosion and water runoff. Local communities use this forest as a grazing land for their cattle. The indigenous trees of the study area are being removed mainly to expand agricultural farm lands and fuel woods and for the construction of houses, fences around their residence, and charcoal production for market. There is also a paper factory that produces effluent and directly discharges it into the Upper Awash River. This study aimed (1) to investigate composition and abundance of macroinvertebrates at different sites in the Upper Awash River, (2) to examine some physicochemical parameters of the water at different sampling sites in the Upper Awash River, (3) to calculate macroinvertebrate metrics along with stressor types, and (4) to assess the impact of environmental stressors on the distribution and abundance of macroinvertebrates in the Upper Awash River.

\section{Materials and Methods}

2.1. Study Area. The Awash River is located in the Dandi District of West Shewa Zone, Oromia Region, Ethiopia, at $9^{\circ} 5^{\prime} \mathrm{N}$ latitude and $38^{\circ} 10^{\prime} \mathrm{E}$ longitude. Ginchi, the district's capital, is located $75 \mathrm{~km}$ west of Addis Ababa, the capital of
Ethiopia. The district has a total area of 109,729 ha ranging from 2000 to 3200 meters above sea level. Based on the 2007 Ethiopian Central Statistical Agency population census, the total population of the Dandi district is 165,803 . The favourable climatic condition for both livestock and crop production has been contributed to the large population in the district. The district has some natural endowments to attract tourists and researchers in which Chilimo Forest is one of them. Chilimo Forest represents the remnants of the dry Afromontane forests in the central plateau of Ethiopia. This district is also known for its rich water resources among which the Awash River and Lake Dandi are the most essential natural resources [20]. The Awash River originates from a high plateau of the district near Ginchi town and flows along the rift valley into the Afar triangle and ends in Lake Abbe [4]. Near Upper Awash River, there is a paper factory that was established in 2009 to produce paper products from used paper. The processed effluent from the factory is directly discharged into the Upper Awash River [21].

2.2. Description of Sampling Sites. The sampling sites were characterized and identified based on physical, chemical, and biological and land-use patterns. Galessa is characterized by the presence of very few cattle, no agricultural activities, and forest site. Arera and Werabo have less human activities while Anjory has relatively high human activities, mainly deforestation and irrigation. Walgata is characterized by the presence of wastes from paper mill factory, whereas Osole has relatively high agricultural activities when compared to other sites. These activities caused the changes among physicochemical parameters, which lead to an impact on the benthic invertebrates of the river, thereby resulting in different faunal composition [5].

2.3. Data Collection. Sampling sites were purposively selected based on their vegetation cover and exposure to various human activities such as agricultural practices, animal grazing, bathing, laundry, watering and drainage of chemical fertilizers from the surrounding lands, and discharges of untreated waste that pollutes the river. Moreover, sites selection was conducted based on the biological, chemical, and physical and land-use patterns. Accordingly, five sampling stations were selected following the rapid bioassessment protocol criteria [21], where different levels of anthropogenic impacts were observed: forest areas with less human impact (Galessa, location-latitude $=38^{\circ} 9^{\prime} 4^{\prime \prime}$, longitude $=9^{\circ} 4^{\prime} 48^{\prime \prime}$, altitude $\left.=2475 \mathrm{~m}\right)$, scattered grazing and agricultural activities (Arera and Werabo, locationlatitude $=38^{\circ} 7^{\prime} 5^{\prime \prime}$, longitude $=9^{\circ} 3^{\prime} 57^{\prime \prime}$, altitude $\left.=2346 \mathrm{~m}\right)$, more grazing and agricultural activities (Anjory, locationlatitude $=38^{\circ} 5^{\prime} 48^{\prime \prime}$, longitude $=9^{\circ} 2^{\prime} 18^{\prime \prime}$, altitude $=2252 \mathrm{~m}$ ), paper mill, industrial wastes and domestic wastes (Walgata, location-latitude $=38^{\circ} 8^{\prime} 5^{\prime \prime}$, longitude $=9^{\circ} 0^{\prime} 42^{\prime \prime}$, altitude $=$ $2200 \mathrm{~m}$ ), and presence of discharges from the paper factory and agricultural activities (Osole, location-latitude $=38^{\circ} 9^{\prime} 2^{\prime \prime}$, longitude $=9^{\circ} 0^{\prime} 04^{\prime \prime}$, altitude $\left.=2176 \mathrm{~m}\right)($ Figure 1) . 




Figure 1: Locations of the study area (Galessa: forest site, Arera: less agriculture, Anjori: high human activities, Walgata: paper mill waste, and Osole: high agriculture).

The Multi-Habitat Sampling (MHS) scheme was used to collect macroinvertebrates larvae [22]. Benthic macroinvertebrates were collected using a standard handheld net $\left(625 \mathrm{~cm}^{2}\right.$, net with mesh size of $500 \mu \mathrm{m}$ from multihabitat units) [23] three times monthly from January 2018 to March 2018. Composite samples consisting of 20 sampling units were taken from each five sites. These 20 sampling units taken for one site at a time were repeated for three times per site and the average was taken. A sampling unit was performed by positioning the net and disturbing the substrate in a quadratic area. Sample collection started at the downstream end and proceeded upstream against water current. In places where the current was low, hand stirrings were used to create currents to push the organisms into the handheld net. Megalithal ( $>40 \mathrm{~cm}$ and bedrock) stones were sampled by brushing the surface approximately equal to the size of the net. Macrolithal $(20-40 \mathrm{~cm})$ stones and emergent macrophytes were picked by hand and their surfaces were brushed to dislodge clingers. After every 3 sampling efforts, the net was rinsed by running clean stream water to avoid clogging. Before preservation, identification of macroinvertebrate taxa/family was performed. Samples were then preserved in $4 \%$ formaldehyde solution for further identification and analysis. Proper records such as stream name and site identity code were maintained with details and the same information was marked on the container with waterproof markers. Along with macroinvertebrates' sampling, microhabitat of the study sites in the river was visually observed and categorized per particle size: psammal $(<0$,
$2 \mathrm{~cm})$, akal $(0,2-2 \mathrm{~cm})$, microlithal $(2-6 \mathrm{~cm})$, mesolithal $(6-20 \mathrm{~cm})$, macrolithal $(20-40 \mathrm{~cm})$, and megalithal $(>40 \mathrm{~cm}$ and bed rock).

The preserved macroinvertebrate samples were brought to Ambo University for further analysis. It was then passed through a set of sieves (2000,500, and $250 \mu \mathrm{m}$ mesh size) to remove formalin and separate size classes of macroinvertebrate groups [4]. Macroinvertebrates trapped in the coarse fraction of the sieve were sorted out and those trapped in the smaller fraction of the sieve were sorted with the help of naked eye and light microscope. Further identification up to the family level was performed using the Aquatic Invertebrates Identification key [24-26] and the identified benthic macroinvertebrates were preserved in plastic vials with $70 \%$ alcohol for further uses.

River water samples for physicochemical parameters were taken 3 times per month at the same location and almost simultaneously with the samples for macroinvertebrates. Water temperature, electrical conductivity, dissolved oxygen (DO), and $\mathrm{pH}$ were measured in situ using a multiprobe (Model HQ40d, HACH Instruments) before sampling the macroinvertebrates. Water samples were collected in 1L polyethylene (solution) bottles and stored in an ice-box and transported to Ambo University for the analysis of nitrate and total phosphorous (TP). Nitrate and total phosphorus were determined through phenoldisulphonic acid method using double beam UV-spectrophotometer (ELICO SL-160) and colorimetric methods, respectively. 
2.4. Data Analysis. Data were analysed by using descriptive and inferential statistics. In addition, biological indices that had been suggested by Rosenberg and Resh [11] were used to determine benthic macroinvertebrate communities and to assess pollution effects on them. Mean values of physicochemical parameters were calculated and compared among five sites (Table 1). We used multidimensional based on environmental variable data to assess the similarity of sampled sites.

In addition to biological indices, data collected for benthic macroinvertebrates and physicochemical parameters were statistically analysed by SPSS version 21 . Correlation was used to analyse relation between benthic macroinvertebrates indices and some physicochemical parameters and the average value (mean $\pm \mathrm{SE}$ ) of core macroinvertebrate metrics selected to determine variability among stressor types and mean difference among the major stressors. One-way ANOVA with Tukey's post hoc test was used to test normality and homogeneity of variance and 0.05 was taken as the significance level.

\section{Result and Discussion}

3.1. Composition and Abundance of Macroinvertebrates. A total of 11,357 individuals of macroinvertebrates, representing seven orders of insects and three classes of noninsects having 28 families were collected from the study area (Table 2). The result showed that macroinvertebrate community structure varied among stressor types. For example, at Walgata (paper mill waste) and Osole (more agricultural activities), red Chironomidae was the most abundant and dominant taxon throughout the sampling period. This finding agreed with the accepted view that tolerant species become abundant in degraded streams and rivers $[18,27,28]$. The percentage of the dominant taxa (\%DT) increased from least impacted site to the more impacted sites while the percentage of Chironomidae (\%Chironomidae) was inversely decreasing from more impacted sites to least impacted site where the river channel consisted of more natural forest coverage and had a vegetation canopy along the channel of the river. Moderately tolerant taxa such as Baetidae, Caenidae, and Hydropsychidae were numerically dominant where human impact was relatively less and agricultural activities were available. Sensitive taxa such as Perlidae, Heptageniidae and Lepidostomatidae were common in forest site (Galessa) and Arera and Werabo (where less agricultural activities and some vegetation were seen).

The diversity and abundances of individuals were lowest in Walgata (paper mill waste) relative to all respective sites which slightly showed a poor quality and dominated with tolerant taxa as the site was impacted by paper mill whose waste was not treated before discharging into river. The result of the study was in accordance with macroinvertebrate community structure reported in Upper Awash River [29].

3.2. Environmental Variables. Environmental variables measured during the sampling period are summarized in Table 1. Accordingly, water quality parameters such as conductivity, $\mathrm{No}_{3}{ }^{-} \mathrm{N}$ concentration, temperature, and total phosphorus showed significant difference among stressor types $(p<0.05)$. The maximum mean water temperature recorded at Osole (more agricultural site) might be due to the absence of vegetation cover and the least mean value recorded at Galessa (forest site) could be related to the presence of some riparian vegetation cover and vegetation within the stream channels. Comparatively, the lowest dissolved oxygen value was recorded at Osole (more agriculture) and this might be due to high water temperature and decomposition process associated with the discharge of organic pollutants from paper mill and urban runoff. The mean EC values at the study area were lower than the hitherto tested rivers in Ethiopia [14, 16, 30]. However, the values of EC in all sampling sites were found in range of EC reported for general freshwaters $(10-1000 \mu \mathrm{S} / \mathrm{cm})$ [5], but below the standard value of EC in surface waters $(1000 \mu \mathrm{S} /$ $\mathrm{cm}$ ) [31]. Relatively, higher values of EC at Walgata (paper mill site) and Osole (more agriculture) might be associated with paper mill and also due to the transport of particulate matters into the streams by mild flood from town and nutrients through runoff from agricultural site, domestic sewage, and enrichment of electrolytes from nearby areas [31].

3.3. Benthic Macroinvertebrate Metrics and Stressor Types. Eight metrics representing richness, composition, and tolerance were selected as core metrics and showed statistically significant difference among stressor types $(p<0.05)$. As presented in Table 3, the average value (Mean \pm SE) of core macroinvertebrate metrics was selected to determine variability among stressor types.

Trends in this study showed that as habitat and water quality are degraded, number and percentage of EPT decreased, while percentages of chironomids increased. Moreover, there were significant correlations between macroinvertebrates and most environmental variables which are in line with other studies $[14,28]$. In addition to this, H-FBI was increased with increasing perturbation as some organic pollutants are entering the river from the surroundings due to human activities. According to Hilsenhoff [32], it is evident that Anjory (where human activities are massive), Arera and Werabo (less agricultural activity), Walgata (paper mill waste), and Osole (more agricultural activities) fell under moderate water quality class, while Galessa (forest site) fell under good water quality class (Table 3).

The Average Score Per Taxon (ASPT) and ETHbios were recorded in all the five sites during the study period. In addition, the description of water quality was done based on ETHbios and ASPT values in each site. According to the suggested ETHbios threshold values, the highest ETHbios values were scored in Galessa and Arera and Werabo (Table 3), with ASPT value greater than 5 indicating good ecological water quality class and slight ecological degradation. However, Anjory, Walgata, and Osole had ASPT value less than 5 that was categorized under moderate ecological water quality class and significant ecological 
TABLE 1: Means and standard deviations for environmental parameters of the study sites.

\begin{tabular}{|c|c|c|c|c|c|}
\hline \multirow{2}{*}{ Parameter } & \multicolumn{5}{|c|}{ Sampling sites } \\
\hline & Galessa & Arera and Werabo & Anjory & Walgata & Osole \\
\hline $\mathrm{pH}$ & $8.78 \pm 0.51$ & $8.57 \pm 0.28$ & $8.72 \pm 0.62$ & $8.69 \pm 0.45$ & $8.58 \pm 0.25$ \\
\hline Conductivity $(\mu \mathrm{S} / \mathrm{cm})$ & $187.04 \pm 20.11^{\mathrm{qrst}}$ & $297.78 \pm 24.06^{\mathrm{prst}}$ & $370.77 \pm 5.65^{\text {pqst }}$ & $465 \pm 32.97 \mathrm{pqr}$ & $472 \pm 31.57 \mathrm{pqr}$ \\
\hline Dissolved oxygen $(\mathrm{mg} / \mathrm{L})$ & $7.69 \pm 0.13$ & $7.68 \pm 1.03$ & $7.39 \pm 0.85$ & $7.26 \pm 0.5$ & $7.4 \pm 0.53$ \\
\hline Dissolved oxygen (\%) & $96.86 \pm 1.72$ & $100.49 \pm 2.49$ & $108.78 \pm 20.43$ & $113.7 \pm 10.69$ & $125.4 \pm 19.38$ \\
\hline Temperature $\left({ }^{\circ} \mathrm{C}\right)$ & $12.49 \pm 1.17^{\mathrm{rst}}$ & $14.9 \pm 2.03^{\mathrm{s}}$ & $20.79 \pm 3.59^{\mathrm{p}}$ & $23.12 \pm 1.2^{\mathrm{pq}}$ & $21.25 \pm 5.41^{\mathrm{p}}$ \\
\hline Total phosphorous (mg/l) & $0.06 \pm 0.01$ & $0.05 \pm 0.01$ & $0.28 \pm 0.41$ & $0.06 \pm 0.01$ & $0.027 \pm 0.05$ \\
\hline $\mathrm{No}_{3}^{-} \mathrm{N}(\mathrm{mg} / \mathrm{L})$ & $0.12 \pm 0.06^{\mathrm{r}}$ & $0.37 \pm 0.24^{\mathrm{r}}$ & $0.83 \pm 0.08^{\mathrm{pqs}}$ & $0.38 \pm 0.22^{\mathrm{r}}$ & $0.48 \pm 0.39$ \\
\hline
\end{tabular}

$\mathrm{p}, \mathrm{q}, \mathrm{r}, \mathrm{s}$, and $\mathrm{t}$ represent stressor types: $\mathrm{p}$, forest site; $\mathrm{q}$, less agriculture; $r$, high human activities; $s$, paper mill waste; $t$, more agriculture that indicates significant mean difference following post hoc tests. $p<0.05$ (Tukey HSD).

TABle 2: Taxa/families identified from the five sampling sites of upper Awash river at Chilimo Forest for a period of three months from January 2018 to March 2018.

\begin{tabular}{|c|c|c|c|c|c|}
\hline \multirow{2}{*}{ Major taxon/family } & \multicolumn{5}{|c|}{ Composition of species (individual $/ \mathrm{m}^{2}$ ) } \\
\hline & Galessa & Arera and Werabo & Anjory & Walgata & Osole \\
\hline \multicolumn{6}{|l|}{ Plecoptera } \\
\hline Perlidae & 61 & 2 & & & \\
\hline \multicolumn{6}{|l|}{ Ephemeroptera } \\
\hline Baetidae & 686 & 800 & 328 & 162 & 197 \\
\hline Caenidae & 270 & 608 & 866 & 583 & 602 \\
\hline Heptageniidae & 252 & 87 & 54 & & \\
\hline Tricorythidae & & 2 & 1 & & \\
\hline \multicolumn{6}{|l|}{ Odonata } \\
\hline Aeshnidae & 2 & 20 & 4 & 2 & 2 \\
\hline Coenagrionidae & & 2 & 83 & 14 & 35 \\
\hline Gomphidae & & & 1 & 3 & 2 \\
\hline \multicolumn{6}{|l|}{ Hemiptera } \\
\hline Belostomatidae & & 2 & 5 & & 2 \\
\hline Gerridae & & & 3 & & 3 \\
\hline Naucoridae & & & 9 & 9 & 10 \\
\hline \multicolumn{6}{|l|}{ Trichoptera } \\
\hline Hydropsychidae & 435 & 413 & 953 & 562 & 353 \\
\hline Lepidostomatidae & 301 & 169 & & & \\
\hline \multicolumn{6}{|l|}{ Coleoptera } \\
\hline Dytiscidae & 8 & 18 & 21 & & \\
\hline Elmidae & 2 & 3 & 13 & 3 & 2 \\
\hline Gyrinidae & 24 & 4 & & 2 & 2 \\
\hline \multicolumn{6}{|l|}{ Diptera } \\
\hline Chironomidae & 108 & 459 & 393 & 589 & 687 \\
\hline Ceratopogonidae & 3 & & & 3 & 4 \\
\hline Tipulidae & 74 & 81 & 3 & 2 & \\
\hline Athericidae & 23 & 6 & 4 & & \\
\hline Simuliidae & 381 & 51 & 140 & 46 & 183 \\
\hline Muscidae & & & 18 & 7 & 59 \\
\hline Tabanidae & 23 & 4 & 8 & 3 & 33 \\
\hline \multicolumn{6}{|l|}{ Heteroptera } \\
\hline Micronectidae & 14 & 41 & 94 & 401 & 482 \\
\hline \multicolumn{6}{|l|}{ Gastropoda } \\
\hline Physidae & & & 81 & 3 & 3 \\
\hline Planorbidae & & & 379 & 4 & 206 \\
\hline \multicolumn{6}{|l|}{ Oligochaeta } \\
\hline Oligochaeta & & 2 & 14 & 38 & 179 \\
\hline \multicolumn{6}{|l|}{ Decapoda } \\
\hline Potamonautidae & 3 & & & 2 & 2 \\
\hline
\end{tabular}

disturbance [33]. This value varies across the stressors type which indicates that there were different kinds of human activities which affected macroinvertebrate composition and distribution.
EPT taxa groups were decreasing from less impacted (Galessa) to more impacted sites (Walgata and Osole) which confirm the sensitivity of these groups to polluted sites. EPT richness was represented mainly by Baetidae, Caenidae, and 
TABLE 3: Biotic indices calculated from all sampling sites.

\begin{tabular}{lccccc}
\hline Metrics & Forest site & Less agriculture & Human activities & Paper mill & More agriculture \\
\hline Family-level richness & $21 \pm 0.92^{\mathrm{r}}$ & $23 \pm 0.58^{\mathrm{rs}}$ & $27 \pm 0.58^{\mathrm{pqst}}$ & $20 \pm 0.58^{\mathrm{qrs}}$ & $23 \pm 0.58^{\mathrm{rs}}$ \\
H-FBI & $4.09 \pm 0.01^{\mathrm{qrst}}$ & $4.97 \pm 0.1^{\mathrm{ps}}$ & $4.92 \pm 0.01^{\mathrm{ps}}$ & $5.15 \pm 0.20^{\mathrm{pr}}$ & $5.08 \pm 0.01^{\mathrm{p}}$ \\
\%EPT & $74.59 \pm 0.32^{\text {rst }}$ & $74.94 \pm 0.81^{\mathrm{rst}}$ & $63.29 \pm 0.21^{\mathrm{pqst}}$ & $53.61 \pm 0.08^{\mathrm{pqrt}}$ & $37.41 \pm 0.31^{\mathrm{pqrs}}$ \\
\%Chironomidae & $4.02 \pm 0.01^{\mathrm{qrst}}$ & $16.51 \pm 0.58^{\mathrm{prst}}$ & $11.29 \pm 0.45^{\mathrm{pqrt}}$ & $24.16 \pm 0.91^{\mathrm{pqr}}$ & $22.31 \pm 1.2^{\mathrm{pq}}$ \\
ETHbios & $107 \pm 1^{\mathrm{st}}$ & $111 \pm 1^{\mathrm{rst}}$ & $105 \pm 1^{\mathrm{qrst}}$ & $84 \pm 2.51^{\mathrm{pqrt}}$ & $91 \pm 1.15^{\mathrm{pqr}}$ \\
ASPT (ETHbios) & $5.95 \pm 0.05^{\mathrm{rst}}$ & $5.84 \pm 0.1^{\mathrm{rst}}$ & $5.22 \pm 0.1^{\mathrm{pqst}}$ & $5 \pm 1^{\mathrm{pqrt}}$ & $4.5 \pm 0.25^{\mathrm{pqrs}}$ \\
Shannon diversity & $2.16 \pm 0.01^{\mathrm{qrst}}$ & $2.06 \pm 0.01^{\mathrm{prst}}$ & $1.93 \pm 0.02^{\mathrm{pqst}}$ & $1.79 \pm 0.01^{\mathrm{pqrt}}$ & $1.68 \pm 0.03^{\mathrm{pqrs}}$ \\
Evenness & $0.274 \pm 0.02^{\mathrm{qrst}}$ & $0.245 \pm 0.01^{\mathrm{prst}}$ & $0.253 \pm 0.01^{\mathrm{pqst}}$ & $0.228 \pm 0.01^{\mathrm{pqrt}}$ & $0.209 \pm 0.02^{\mathrm{pqrs}}$ \\
\hline
\end{tabular}

$\mathrm{p}, \mathrm{q}, \mathrm{r}, \mathrm{s}$, and $\mathrm{t}$ represent stressor types: $\mathrm{p}$, forest site; $\mathrm{q}$, less agriculture; $r$, human activities; $s$, paper mill waste; $t$, more agriculture that indicates significant mean difference following Bonferroni post hoc tests. $p<0.05$ (Tukey HSD).

Hydropsychidae throughout the sampling period and thus decreasing number of these taxa improved the performance of EPT metrics in more impacted sites. Biotic scores are widely used in water quality assessments because of their advantage in providing information on specific taxon response to disturbance other than diversity. This could be the reason that ASPT-ETHbios [4] revealed high discrimination efficiency between stressor types.

Comparison of benthic macroinvertebrates between the five sites showed variation in evenness and Shannon Diversity Index. Galessa showed the largest value of Shannon diversity index $\left(\mathrm{H}^{\prime}=2.16\right)$, followed by Arera $\left(\mathrm{H}^{\prime}=2.06\right)$, Anjori $\left(\mathrm{H}^{\prime}=1.93\right)$, Walgata $(1.79)$, and Osole $\left(\mathrm{H}^{\prime}=1.68\right)$. The highest values of evenness were recorded in Galessa, followed by Anjory, Arera, Walgata, and Osole, with the value of $0.274,0.253,0.245,0.228$, and 0.209 , respectively. The value differences across the stressors type might be due to differences in human activities among the five sites.

3.4. Correlation between Macroinvertebrates and Environmental Parameters. Correlation analysis between macroinvertebrate metrics and the environmental variables indicated significant correlation $(p<0.05)$. Environmental variables that showed correlation with benthic macroinvertebrates metric were dissolved oxygen, conductivity, and temperature (Table 4). These parameters are reported as good indicators of organic pollution $[22,34-36]$. The impairment at Walgata is high because of waste discharge from the paper mill in the study area.

Conductivity was negatively correlated with Shannon Diversity Index, \%EPT, and evenness and positively correlated with \%Chironomidae. On the other hand, dissolved oxygen $(\mathrm{mg} / \mathrm{l})$ was positively correlated with ETHI-bios index while water temperature $\left(\mathrm{C}^{\circ}\right)$ was negatively correlated with ETHbios index.

The result showed that anthropogenic activities have effect on abundance and distribution of benthic macroinvertebrates [5]. All sites were classified based on environmental variables associated with them. Due to this, overall benthic macroinvertebrates recorded in the study revealed differences in composition, distribution, and abundance along different sites of Upper Awash River (Table 2). The differences appeared to be related primarily to the habitat conditions and secondarily to the influence of environmental factors, such as the human induced pollutants, especially agricultural practice, nature of the area, and tolerance value of benthic macrofauna. The result of the study was in accordance with macroinvertebrate community structure reported in Upper Awash River previously by Lakew [29] which stated that trend in the benthic community was observed to predict alterations caused by different stressors, mainly the point source pollution, as the case in paper mill waste.

The upper part of the river (Galessa) becomes pristine; most fauna can inhabit it; and there might be high competition, which can thus support fewer macroinvertebrates than the lower part of the river (Walgata and Osole). Mild pollution has also a tendency to increase the total abundance and even diversity $[18,37]$.

Comparatively, Oligochaeta was also most abundant at Walgata (paper mill waste) and Osole (high agricultural practices). This finding agreed with the accepted view that tolerant species become abundant in degraded streams and rivers $[18,28,33]$. The percentage of the dominant taxa $(\%$ DT) increased from least impacted site to the more impacted sites while the percentage of Chironomidae inversely decreased from more impacted sites to least impacted site where the river channel consists of more natural forest coverage and had a vegetation canopy. The large abundance of Chironomidae at Walgata and Osole might be an indication of organic pollution and nutrient enrichment because Chironomidae increases with decreasing water quality. Therefore, the present result mentioned at above sites agreed with that of Weigel et al. [38] who reported that Chironomidae were taxa at sites with severe point source pollution. Several studies have shown that high abundance of tolerant benthic macroinvertebrate and low diversity of sensitive taxa were registered in impacted streams [39, 40]. On the other hand, moderately tolerant families such as Baetidae, Caenidae, and Hydropsychidae were numerically dominant at Galessa, Arera and Werabo, and Anjory where human impact was relatively less and agricultural activities were available. 
TABLE 4: Bivariate Spearman correlation between benthic macroinvertebrates indices and some physicochemical parameters.

\begin{tabular}{|c|c|c|c|c|c|c|}
\hline Env't Par & \%Chiro & SDI & Evenness & $\% \mathrm{EPT}$ & H-FBI & ETHbios \\
\hline Conductivity $(\mu \mathrm{S} / \mathrm{cm})$ & $0.800^{*}$ & $-0.900^{*}$ & $-0.900^{*}$ & $-0.900^{*}$ & 0.800 & -0.800 \\
\hline Dissolved oxygen $(\mathrm{mg} / \mathrm{L})$ & -0.738 & 0.580 & 0.580 & 0.791 & -0.738 & $0.949^{*}$ \\
\hline Water temperature $\left(\mathrm{C}^{\circ}\right)$ & 0.900 & -0.800 & -0.800 & -0.800 & $0.900^{*}$ & $-0.900^{*}$ \\
\hline $\mathrm{TP}(\mathrm{mg} / \mathrm{L})$ & 0.154 & 0.154 & -0.154 & -0.667 & 0.154 & -0.667 \\
\hline $\mathrm{No}_{3}{ }^{-} \mathrm{N}(\mathrm{mg} / \mathrm{L})$ & 0.205 & -0.359 & -0.359 & -0.462 & 0.205 & -0.308 \\
\hline
\end{tabular}

${ }^{*}$ Correlation is significant at 0.05 levels (2-tailed).

\section{Conclusion}

The study depicted the negative impacts of anthropogenic activities on water quality and composition, diversity, and distribution of benthic macroinvertebrates in the Upper Awash River. Agricultural activities, the discharge of sewage, and poor solid waste management were the major environmental stressors responsible for the deterioration of the water. These stressors caused changes in benthic macroinvertebrate communities which clearly reflect the impact of the stressor either on water quality or on habitat degradation. A trend in the benthic community was observed to predict alterations caused by different stressors, mainly the point source pollution, as the case in paper mill waste and agricultural site waste. A change in physicochemical water quality parameters driven mainly by anthropogenic activities harmed benthic macroinvertebrates. In addition, the correlation analysis demonstrated relationship between sensitive benthic invertebrate indices and environmental variables that indicated ecological disturbances. Based on the current result, we recommend that environmental protection agencies of governmental and nongovernmental organizations should raise awareness of the local people so that they reduce activities that affect the river. Paper factory should also monitor its effluent from directly discharging into the Upper Awash River.

\section{Data Availability}

All the data supporting the results of this study have been included in the manuscript.

\section{Conflicts of Interest}

The authors declare that they have no conflicts of interest.

\section{Acknowledgments}

The authors would like to thank Ambo University to organize this research work and LARIMA project of Austrian Development Cooperation for financial support. The authors also thank National Fishery and Aquatic Life Research Center for arranging field and laboratory facilities being with the Ambo University.

\section{References}

[1] B. Aylward, J. Bandyopadhyay, and J. C. Belausteguigotia, "Freshwater ecosystem services," Ecosyst Hum Well Being Policy Responses, vol. 3, pp. 213-254, 2005.
[2] Z. Gebremaria and E. Dadebo, "Water resources and fisheries management in the Ethiopian rift valley lakes," Sinet: Ethiopian Journal of Science, vol. 12, pp. 95-109, 1989.

[3] S. T. Mereta, P. Boets, L. De Meester, and P. L. M. Goethals, "Development of a multimetric index based on benthic macroinvertebrates for the assessment of natural wetlands in southwest Ethiopia," Ecological Indicators, vol. 29, pp. 510521, 2013.

[4] A. Lakew, Development of biological monitoring systems using benthic invertebrates to assess the ecological status of central and southeast highland rivers of Ethiopia, Ph.D. thesis, p. 163, University of Natural Resources and Life Sciences, Vienna, Austria, 2014.

[5] D. Chapman and V. Kimstach, Selection of Water Quality Variables, pp. 243-318, , E\&FN Spon, Cambridge, England, 1996, Water Quality Assessments. A guide to the use of biota, sediments and water in environmental Monitoring.

[6] J. Bartram and R. Balance, Water Quality Monitoring-A Practical Guide to the Design and Implementation of Freshwater Quality Studies and Monitoring Programmes, NEP/ WHO, Geneva, Switzerland, 1996.

[7] W. Legesse, P. S. Giller, and J. O'Halloran, "Physicochemical and biological assessment of the kebena river," $\mathrm{Ph}$. D. thesis, National University of Ireland, Addis Ababa, Ethiopia, 2000.

[8] World Health Organization, "Water supply and Sanitation operation and maintenance of urban water supply and sanitation systems: a guide for manager," WHO Bulletin, vol. 63, no. 2, p. 273, 1995.

[9] J. L. Metcalfe, "Biological water quality assessment of running waters based on macroinvertebrate communities: history and present status in europe," Environmental Pollution, vol. 60, no. 1-2, pp. 101-139, 1989.

[10] J. M. Hellawell, Biological Indicators of Freshwater Pollution and Environmental Management, p. 546, Elsevier, Amsterdam, Netherlands, 1986.

[11] D. M. Rosenberg and V. H. Resh, Introduction to Freshwater Biomonitoring and Benthic Macroinvertebrates, D. M. Rosenberg and V. H. Resh, Eds., , Chapman and Hall, London, UK, 1993pp. 1-9, Freshwater biomonitoring and benthic macroinvertebrates.

[12] P. Armitage, D. Moss, J. Wright, and M. Furse, "The performance of a new biological water quality score system based on macroinvertebrates over a wide range of unpolluted running-water sites," Water Research, vol. 17, no. 3, pp. 333-347, 1983.

[13] J. N. Negishi, M. Inoue, and M. Nunokawa, "Effects of channelization on stream habitat in relation to a spate and flow refugia for macroinvertebrates in northern Japan," Freshwater Biology, vol. 47, no. 8, pp. 1515-1529, 2002.

[14] B. Sitotaw, "Macro-invertebrates assemblage structure in relation to environmental degradation in some Ethiopian Rivers," M. S. thesis, School of Graduate Studies, Addis Ababa University, Addis Ababa, Ethiopia, 2006. 
[15] S. Akalu, S. Mengistu, and S. Leta, "Assessing human impacts on the Greater Akaki River, Ethiopia using macroinvertebrates," Sinet: Ethiopian Journal of Science, vol. 34, no. 2, pp. 89-98, 2011.

[16] A. Tassew, Assessment of Biological Integrity Using PhysicoChemical Parameters and Macro-Invertebrate Community Index along Sebeta River, Ethiopia, Addis Ababa University, Addis Ababa, Ethiopia, 2007.

[17] A. Lakew, "Applicability of bio-assessment methods using benthic Macro-invertebrates to evaluate the ecological status of highland streams and Rivers in Ethiopia," M. S. thesis, UNESCO-IHE Delft, Delft, Netherlands, 2007.

[18] B. Abay, "Assessment of downstream pollution profiles of awassa textile factory effluent along tikurwuha river using physico-chemical and macro-invertebrate indicators, Ethiopia," M. S. thesis, Addis Ababa University, Addis Ababa, Ethiopia, 2007.

[19] T. Addis, "Comparative study of macro-invertebrates and diatoms as bio-indicators of river water quality in Addis Ababa," M. S. thesis, Addis Ababa University, Addis Ababa, Ethiopia, 2008.

[20] M. Bekele, "Forest Property Right, the role of the state and institutional exigency: the Ethiopian experience," $\mathrm{Ph}$. D. thesis, Swedish University of Science, Uppsala, Sweden, 2003.

[21] Z. F. Jebessa and E. B. Wondemagegnehu, "Physicochemical characterization of upper Awash River of Ethiopia polluted by anmol product paper factory," International Journal of Water and Wastewater Treatment, vol. 4, no. 2, pp. 1-10, 2018.

[22] O. Moog and S. Sharma, Guidance for Pre-classifying the Ecological Status of HKH Rivers, Deliverable 7b for ASSESS$\mathrm{HKH}$, European Commission, Luxembourg, Europe, 2005.

[23] A. Doretto, T. Bo, F. Bona, and S. Fenoglio, "Efficiency of Surber net under different substrate and flow conditions: insights for macroinvertebrates sampling and river biomonitoring," Knowledge and Management of Aquatic Ecosystems, vol. 421, no. 10, pp. 1-4, 2020.

[24] A. M. Gerber and J. M. Gabriel, Aquatic Invertebrates of South African Rivers, Field Guide, Institute for Water Quality studies, Department of Water Affairs and Forestry, Pretoria, South Africa, 2002.

[25] R. W. Merritt and K. W. Cummins, An Introduction to the Aquatic Insects of North Americap. 862, 3rd edition, Kendall/ Hunt Publishing, Dubuque, IA, USA, 1996.

[26] K. M. F. Scott, On the Hydropschidae (Trichoptera) of South African with Keys to Africa Genera of Maggots, Larvae, and Pupa and Species List, Annals of the cape provincial Museum, Natural History, Grahamstown, South Africa, 1983.

[27] M. Teferi, T. Haileselasie, T. Asmelash et al., "Influence of water quality on the diversity and distribution of macroinvertebrates in highland stream, Northern Ethiopia," Journal of Agricultural Science, vol. 2, no. 2, pp. 17-25, 2013.

[28] L. Aschalew and O. Moog, "A Multimetric index based on benthic macroinvertebrates for assessing the ecological status of streams and rivers in central and southeast highlands of Ethiopia," Hydrobiologia, vol. 751, pp. 229-242, 2015.

[29] A. Lakew, "Assessing Anthropogenic impacts using benthic macro invertebrates as bio-indicator in central highland streams of Ethiopia," Ethiopian Journal of Environmental Studies and Management, vol. 8, no. 1, 2015.

[30] S. Leta, F. Assefa, and D. Gunnel, "Characterization of Tannery waste water and assessment of downstream pollution profiles along Modjo River in Ethiopia," Ethiopian Journal of Biological Sciences, vol. 2, no. 2, pp. 157-168, 2003.
[31] F. Beksisa, A. Lakew, P. Devi, and W. Graf, "Macroinvertebrate communities in the spring and stream sites of upper Awash River at Chilimo, Ethiopia," Innovative Techniques in Agriculture, vol. 13, pp. 141-151, 2016.

[32] W. L. Hilsenhoff, "Rapid field assessment of organic pollution with a family-level biotic index," Journal of the North American Benthological Society, vol. 7, no. 1, pp. 65-68, 1988.

[33] L. Aschalew and O. Moog, "Benthic macroinvertebrates based new biotic score "ETHbios" for assessing ecological conditions of highland streams and rivers in Ethiopia," Limnologica, vol. 52, pp. 11-19, 2015b.

[34] M. T. Barbour, J. Gerritsen, B. D. Snyder, and J. B. Stribling, Rapid Bioassessment Protocols for Use in Streams and Wadeable Rivers: Periphyton, Benthic Macroinvertebrates and Fish, U.S. Environmental Protection Agency, Office of Water, Washington, DC, USA, 2nd edition, 1999.

[35] J. W. Owens, "The hazard assessment of pulp and paper effluents in the aquatic environment: a review," Environmental Toxicology and Chemistry, vol. 10, no. 12, pp. 1511-1540, 1991.

[36] C. J. Biermann, Pulping and Paper MakingAcademic Press, Cambridge, MA, USA, 1996.

[37] F. R. Hauer and G. A Lamberti, Benthic Macro-Invertebrates Methods in Stream Ecology, Academic Press, Cambridge, MA, USA, 1996.

[38] B. M. Weigel, L. J. Henne, and L. M. Martínez-Rivera, "Macro-invertebrate based index of biotic integrity for protection of streams in west-central Mexico," Journal of the North American Benthological Society, vol. 21, no. 4, pp. 686-700, 2002.

[39] M. J. Hall, G. P. Closs, and R. H. Riley, "Relationships between land use and stream invertebrate community structure in a South Island, New Zealand, and Coastal stream," New Zealand Journal of Marine and Freshwater Research, vol. 35, no. 3, pp. 591-603, 2001.

[40] C. J. Walsh, A. K. Sharpe, P. F. Breen, and J. A. Sonneman, "Effects of urbanization on streams of the Melbourne region, Victoria, Australia: benthic macro-invertebrate communities," Freshwater Biology, vol. 46, no. 4, pp. 535-551, 2001. 